\title{
Short cervix in twin pregnancies: current state of knowledge and the proposed scheme of treatment
}

\author{
Hubert Huras ${ }^{1}$, Jarosław Kalinka², Romuald Dębski ${ }^{3}$ \\ ${ }^{1}$ Department of Obstetrics and Perinatology, Jagiellonian University Medical College in Krakow, Poland \\ ${ }^{2}$ Department of Perinatology, Medical University of Lodz, Poland \\ ${ }^{3}$ Department of Gynecology and Obstetrics, Centre of Postgraduate Medical Education, Bielanski Hospital, Poland
}

\begin{abstract}
Short cervical length (SCL) should be defined as a cervical length (CL) less than $25 \mathrm{~mm}$ between 18 and 22 weeks of gestation. This definition of $\mathrm{SCL}$ is fully applicable for singleton pregnancies, but is not entirely correct for twin pregnancies. Thus far, there are no explicit guidelines on the treatment of twin pregnancy with a SCL.

The use of progesterone in the treatment of SCL, and preterm birth (PTB) prophylaxis, is one of the interventions recommended by the Polish Ministry of Health for cervical shortening in singleton pregnancies. In twin pregnancies, attention should be paid to the potential benefits of using vaginal progesterone in the reduction of neonatal mortality as well as lowering the incidence of neonatal complications; specifically in a group of patients with twin pregnancies and $\mathrm{CL}$ less than $25 \mathrm{~mm}$ or below the $10^{\text {th }}$ percentile for the gestational age, measured between 18 and 22 weeks of gestation.

It remains difficult to ascertain the benefits of using pessaries in the prevention of PTB in twin pregnancies. The usage of pessaries appears to be beneficial only in selected subpopulations of patients with asymptomatic CLs less than $25 \mathrm{~mm}$ or 10th percentile for gestational age.

The use of cervical cerclage in PTB prevention in twin pregnancies is limited to cases where the external cervical dilation is $>1 \mathrm{~cm}$ and $<4 \mathrm{~cm}$ between 16 and 24 weeks of gestation.

Considering the necessity for screening for asymptomatic shortening of the cervix in twin pregnancies, establishing a standard practice in the case of positive screening results is seemingly crucial.
\end{abstract}

Key words: twin pregnancy, cervical insufficiency, pessary, cervical cerclage, progesterone, pregnancy complication

Ginekologia Polska 2017; 88, 11: 626-632

\section{INTRODUCTION}

Cervical incompetence $(\mathrm{Cl})$ is defined as a painless dilation and shortening of the cervix in the absence of vaginal bleeding, uterine contraction and the preterm rupture of membranes, ending with either miscarriage or childbirth during the second trimester of pregnancy [1]. $\mathrm{Cl}$ is part of a broader concept of a short cervix. Short cervical length (SCL) should be defined as a CL less than $25 \mathrm{~mm}$ between 18 and 22 weeks of gestation. This definition of SCL is fully applicable for singleton pregnancies and is used in the treatment recommendations, but does not entirely apply towards twin pregnancies. A number of authors and medical associations suggest to define the short cervix as a cervical length below the 10th percentile for a given gestational age. In the pathogenesis of the short cervix, both congenital factors (e.g. anatomical anomalies) and acquired factors may play an important role, including: cervical surgery, cervical trauma and systemic diseases associated with collagen and elastin disorders, as well as excessive mechanical pressure exerted on the cervix [2,3].

Cervical length evolves during pregnancy and diminishes with the duration of pregnancy. The dynamics and degree of these changes depend on the number of fetuses [4]. In cases involving multiple pregnancies, it is difficult to clearly define the boundaries between the pathological shortening of the cervix due to its dysfunction and the natural processes that occur during pregnancy which are exacerbated by the presence of more than one fetus. 
So far, there are no explicit guidelines on the treatment of twin pregnancy with excessive cervical shortening. Current recommendations for short cervix established for singleton pregnancies cannot be fully utilised in patients with twin pregnancy, presumably due to different mechanisms that lead to cervical shortening. Delineating the treatment protocol in twin pregnancies is essential in order to reduce the preterm birth (PTB) rate, as there are efficient methods for early detection of short cervix.

\section{DIAGNOSIS OF SHORT CERVIX IN TWIN PREGNANCY}

According to the standards of perinatal care, constituted by the Polish Ministry of Health, patients with twin pregnancy should have a transvaginal ultrasound examination with a cervical length $(\mathrm{CL})$ measurement performed between 18 and 22 weeks of gestation. If the $C L$ is less than $25 \mathrm{~mm}$ in a given period, the patient should be classified as having an increased risk of PTB [5]. Apart from the obligations to conduct screenings for asymptomatic cervical shortening for the general population, the current guidelines outlined by the Ministry of Health clearly solely define the possible treatment strategies in singleton pregnancies, without taking into account twin pregnancies that carry an increased risk of PTB [5].

The benefit of screening for the asymptomatic shortening of the cervix in twin pregnancy has been repeatedly confirmed in available literature [6-8]. In 1996, Goldenberg et al. showed that a CL less than $25 \mathrm{~mm}$ at 24 weeks of gestation is associated with an increased risk of PTB before 37 weeks of gestation [OR 6.9; 95\% Cl 2.0-24.2)] [9]. In the meta-analysis by Conde-Agudelo, Romero et al. [10], the results of 21 studies on cervical length measurements in twin pregnancy were evaluated. It has been shown that a CL less than $20 \mathrm{~mm}$ between 20 and 24 weeks gestation increases the risk of PTB before 32 weeks of gestation from $6.8 \%$ to $42.4 \%$, and the risk of PTB before 34 weeks of gestation from $15.3 \%$ to $61.9 \%$, respectively. Moreover, a CL less than $25 \mathrm{~mm}$ appeared to increase the risk of PTB before 28 weeks of gestation from $3.5 \%$ to $25.8 \%$ and from $41.2 \%$ to $75.5 \%$ before 37 weeks of gestation [10].

Recent studies indicate that serial cervical length measurements in twin pregnancies may provide a better tool for screening for cervical shortening. The study by Melamed et al. [11], published in the American Journal of Obstetrics and Gynecology in 2016, indicates the benefits of serial cervical length measurements using transvaginal ultrasound in patients with high risk for PTB before 32 weeks of gestation. In this study, a total of 441 patients with twin pregnancies underwent serial measurements of cervical length between 18 and $21+6$ (period 1), 22 and $24+6$ (period 2), 25 and $27+6$ (period 3 ) and 28 and 32 and 32 (Period 4) weeks of gestation. Both values - absolute cervical length and the degree (in percentages) of cervical shortening - were compared during respective periods. There was a statistically significant association between cervical length below the 10th percentile in each of the 4 periods and an increased risk of PTB before 32 weeks of gestation [period $1-\mathrm{RR}=7.2(3.1-16.5)$, period $2-\mathrm{RR}=15.3(6.4-36.7)$, period $3-R R=10.3$ (4.4-24.3), period $4-R R=23.1$ (8.3-64.1)]. Furthermore, the advantage of serial cervical length measurements was demonstrated. In relation to the single measurement in period 1, the serial cervical length measurements in all 4 periods were associated with an increased detection rate of PTB prior to 32 weeks of gestation $(69 \%$ vs. $28 \%$ for single measurement, $p<0.001$ ), increased positive predictive value (14.54 vs. 5.21) and decreased negative predictive value ( $0.32 \mathrm{vs.} 0.76)$. The results of the study imply the practicality of defining the short cervix as shorter than 10th percentile for a given gestational age and the clinical relevance of serial cervical length measurements in the prevention of preterm labour.

Funneling of the internal cervical os could also be used as an additional tool in the prediction of PTB in twin pregnancies. A paper by Vayssière et al. [12] assesses the accuracy of cervical length and funneling of the internal os in the prediction of PTB in twin pregnancies. The results for internal os funneling showed that the sensitivity of funneling measured at 22 weeks of gestation in prediction of PTB $<32$ and 35 weeks of gestation were $54 \%$ and $33 \%$; and their specificity was $89 \%$ and $91 \%$, respectively. For PTB $<32$ and 35 weeks of gestation, the sensitivity of $\mathrm{CL} \leq 30 \mathrm{~mm}$ measured at 22 weeks of gestation was $46 \%$ and $27 \%$, respectively; the specificity was $89 \%$ and $90 \%$, respectively. Funneling measurements at 27 weeks of gestation exhibited sensitivity values of $86 \%$ and $54 \%$ and specificity values of $78 \%$ and $82 \%$ in predicting PTB at $<32$ and 35 week of gestation. For PTB $<32$ and 35 weeks of gestation, the sensitivity of cervical length $\leq 25 \mathrm{~mm}$ measured at 27 week of gestation was correspondingly $100 \%$ and $54 \%$, and the specificity was $84 \%$ and $87 \%$, respectively [12].

Another possible tool for predicting PTB is the detection of the cervical gland area. A paper by Yoshimatsu et al. [13] showed that in the normal pregnancy group (260 singleton pregnancies), the detection rate of the cervical gland area remained practically constant until the 31st week of pregnancy (97\%), but substantially decreased thereafter (70.2\% in gestational weeks 32-35). In the threatened PTB group (101 singleton pregnancies), the detection rate of the cervical gland area was consistently lower (44.5\%) [13]. Unfortunately, the current research on the usefulness of cervical gland detection in predicting PTB in twin pregnancies is lacking. 


\section{PHARMACOLOGICAL METHODS - ROLE OF THE PROGESTERONE IN THE PROPHYLAXIS OF SHORT CERVIX}

The use of progesterone in the treatment of $\mathrm{SCL}$ and PTB prophylaxis is one of the interventions recommended by the Polish Ministry of Health for cervical shortening in singleton pregnancies [5]. This procedure is proven efficacious and has been repeatedly verified in clinical trials. In 2012, Romero, Nicolaides et al. [14] published a meta-analysis of randomized clinical trials on vaginal progesterone in pregnant women with asymptomatic shortening of cervix in the second trimester of pregnancy. The decrease was noted in PTB before 28 weeks of gestation (RR 0.51; $95 \% \mathrm{Cl}$ $0.31-0.85$ ), before 33 weeks of gestation (RR $0.56,95 \% \mathrm{Cl}$ $0.40-0.80$ ) and before 35 weeks of gestation (RR 0.67; 95\% $\mathrm{Cl}$ 0.51-0.87). In addition, the use of vaginal progesterone was associated with a reduction in neonatal mortality and neonatal morbidity (RR 0.59; 95\% Cl 0.38-0.91). However, for twin pregnancies with asymptomatic cervical shortening, with a CL less than $25 \mathrm{~mm}$ in the second trimester, a statistically insignificant trend toward a reduction in the prevalence of PTB before 33 weeks was demonstrated; moreover, vaginal progesterone was shown to be associated with a $48 \%$ reduction in neonatal mortality and the incidence of neonatal complications (RR 0.52; 95\% Cl 0.29-0.93) [14]. These observations were confirmed by Schuit et al. in a meta-analysis of vaginal progesterone, in patients with twin pregnancies, in order to reduce the incidence of neonatal complications [15]. It has been shown that the routine use of vaginal progesterone in all twin pregnancies does not reduce neonatal mortality or neonatal morbidity (RR 0.97 ; $95 \% \mathrm{Cl} 0.77-1.2)$. Nonetheless, in a selected subgroup of patients with $\mathrm{CL}$ less than $25 \mathrm{~mm}$ before 24 weeks of gestation, vaginal progesterone significantly reduced neonatal mortality and the incidence of neonatal complications (RR 0.56; 95\% Cl 0.42-0.75) [15].

The daily recommended dose of progesterone is $90 \mathrm{mg}$ in gel and $200 \mathrm{mg}$ in vaginal tablets (100 mg twice a day) [14]. The efficacy of higher doses of progesterone (400 mg) in the reduction of PTB, neonatal mortality and morbidity was not demonstrated. Furthermore, a statistically insignificant trend toward a higher incidence of pregnancy cholestasis was shown in a subgroup of patients receiving higher doses of progesterone [16].

In conclusion, attention should be paid to the potential benefits of using vaginal progesterone in the reduction of neonatal mortality and the incidence of neonatal complications in the group of patients with twin pregnancies - $\mathrm{aCL}$ of less than $25 \mathrm{~mm}$ or below the 10th percentile for the gestational age - measured between 18 and 22 weeks of gestation.

\section{MECHANICAL METHODS — USE OF PESSARIES AND CERVICAL CERCLAGE FOR THE TREATMENT OF SHORT CERVIX IN TWIN PREGNANCIES}

The unequivocal benefits of using pessaries in the prevention of $S C L$ in twin pregnancies have not been established, as the results of clinical trials are contradictory. In 2013, the results of the ProTWIN study published in the Lancet, evaluated the efficacy of pessaries in PTB prophylaxis in twin pregnancies [17]. There were no statistically significant differences in the obstetric or neonatal outcomes in the group of patients with pessaries administered between 16 and 20 weeks of gestation. The use of pessaries did not reduce PTB in $<28,<32$ and $<37$ weeks of gestation (RR 0.79, 95\% Cl 0.50-1.27; RR 0.86, 95\% Cl 0.65-1.15; RR 0.94, $95 \% \mathrm{Cl} 0.87-1.07$, respectively). There were no differences in the incidence of neonatal complications (RR 0.98; $95 \%$ $\mathrm{Cl}$ 0.69-1.39). However, it is worth to note that in the analysis of the subgroup of patients whose cervical length, between 16 and 20 weeks, was less than the 25 th percentile (corresponding to $38 \mathrm{~mm}$ in the study population), pessary administration resulted in statistically significant prolongation of pregnancy ( $p=0.0106$, RR $0.49 ; 95 \% \mathrm{Cl} 0.32-0.77$ ). In addition, the incidence of neonatal complications was statistically significantly lower $(p=0.0106, R R 0.4,95 \% \mathrm{Cl}$ 0.19-0.83), as well as the risk of PTB before 28 weeks of gestation ( $p=0.0158, \mathrm{RR} 0.23,95 \% \mathrm{Cl}<0.06-0.87)$ and before 32 weeks of gestation ( $p=0.0476, \mathrm{RR} 0.49 ; 95 \% \mathrm{Cl} 0.24-0.97$ ). This study shows that in twin pregnancies the norms for $\mathrm{CL}$, in comparison to the norms of $C L$ for singleton pregnancies, are different. As such, the treatment should be initiated in twin pregnancies even if the results are within the norms for $\mathrm{CL}$ in the singleton pregnancies.

In 2016, the results of two randomised clinical trials were published almost simultaneously in the American Journal of Obstetrics and Gynecology. The initial publication in January, by Goya et al. [18], evaluated the efficacy of pessaries administered between 20 and 24 weeks of gestation in the prevention of PTB among twin pregnancies. There were no statistically significant differences in the incidence of PTB before 34 weeks of gestation (RR 1.054, 95\% Cl 0.787-1.413) as well as neonatal mortality (RR 0.908, 95\% Cl 0.553-1.491), neonatal complications (RR 1.094; 95\% Cl 0.851-1.407) and the incidence of neonatal intensive care procedures (RR 1.040; 95\% Cl 0.871-1.242).

As evidenced in the ProTWIN study, there was a post-hoc analysis of the subgroup of patients with a CL less than $25 \mathrm{~mm}$ between 20 and 24 weeks of gestation, but there were no statistically significant differences in incidence of PTB before 34 weeks of gestation as well as no reduction in neonatal complications. 
Previously discussed conflicting results are partially clarified in the PECEP-Twins study published in February 2016 in the American Journal of Obstetrics and Gynaecology. The study evaluates the use of pessaries in PTB prevention in twin pregnancies with an asymptomatic short cervix [19]. Patients with a cervical length less than $25 \mathrm{~mm}$ between 18 and 22 weeks of gestation were included in the study. The use of pessaries significantly reduced the incidence of PTB before 34 weeks of gestation (RR $0.41 ; 95 \% \mathrm{Cl} 0.22-0.76$ ). In addition, the use of pessaries was associated with a statistically significantly lower risk of birth weight less than $2500 \mathrm{~g}$ (RR 0.72; 95\% Cl 0.54-0.97). However, these changes did not affect the incidence of neonatal complications (RR 0.64; $95 \% \mathrm{Cl} 0.27-1.50)$. Moreover, the incidence of side effects resulting from pessary usage was assessed in the study. However, despite a significant increase in rate of excessive vaginal discharge (100\% in the study group vs. $53 \%$ in the control group), this did not result in the increased number of bacteriologically positive vaginal swabs and the necessity for antibiotic therapy.

Taking into consideration the results of the mentioned studies, it is still difficult to clearly identify the benefits of using pessaries in the prevention of PTB in twin pregnancies. The usage of pessaries appears to be beneficial only in selected subpopulations of patients presenting with an asymptomatic $\mathrm{CL}$ less than $25 \mathrm{~mm}$ or 10 th percentile for gestational age.

The benefits of cervical cerclage in the prevention of PTB in twin pregnancies have not been unequivocally identified and, in addition, this procedure is controversial. The guidelines issued by the American College of Obstetricians and Gynaecologists (ACOG), the Society of Obstetricians and Gynaecologists of Canada (SOGC), and the Royal College of Obstetricians and Gynaecologists (RCOG) do not recommend the use of cervical cerclage in the prevention of PTB in twin pregnancies, as there are reports that such intervention may increase the risk of preterm delivery in this group of patients [20-22]. In 2005, Berghella et al. [23] published a meta-analysis of 4 randomized clinical trials that assessed the efficacy of cervical cerclage in both single and multiple pregnancies. Additionally, a subgroup of twin pregnancies with a CL less than $25 \mathrm{~mm}$, confirmed via ultrasound, was selected. The research showed that in this group, the increased risk of PTB before 35 weeks of gestation was statistically significant (RR 2.15, 95\% Cl 1.15-4.01), and there was a statistically insignificant increased risk of neonatal death [RR 2.66; 95\% Cl 0.83-8.54). However, a retrospective cohort study by Roman et al. [24], published in 2016 in the American Journal of Obstetrics and Gynaecology, indica- tes that the use of cervical cerclage can be beneficial in a selected group of women with twin pregnancies. The analysis included perinatal and neonatal outcomes in twin pregnancies, with cervical dilation ranging from 1 to $4 \mathrm{~cm}$, that underwent cervical cerclage between 16 and 24 weeks of gestation. A statistically significant reduction of PTB at $<34,<32,<28$ and $<24$ weeks of gestation was observed in this group of patients ( $\mathrm{p}<0.05), 95 \% \mathrm{Cl} 0.03-0.34$, aOR $0.08,95 \%$ Cl 0.03-0.34 AOR 0.05; 95\% Cl 0.01-0.2; aOR 0.17; $95 \% \mathrm{Cl} 0.05-0.54$, respectively). In addition, there was a reduction in neonatal mortality (aOR $0.24,95 \% \mathrm{Cl} 0.11-0.5$ ) as well as neonatal complications (aOR $0.05 ; 95 \% \mathrm{Cl} 0.01-0.21$ ).

Based on the results of the aforementioned research, it appears that the use of cervical cerclage for PTB prevention in twin pregnancies is limited to cases where the external cervical dilation is $>1 \mathrm{~cm}$ and $<4 \mathrm{~cm}$, between 16 and 24 weeks of gestation. The current data pertaining to the efficacy of cervical cerclage - in the group of patients exhibiting a shortened cervix without dilation - are conflicting and prove difficult in providing a definitive conclusion.

\section{SUMMARY}

Considering the necessity of screening patients with twin pregnancies for asymptomatic shortening of the cervix, establishing a standard practice in the case of a positive screening result is crucial. Based on the aforementioned data derived from the previously discussed medical literature, summarised in Table 1, the proposed algorithm is presented in Figure 1. All women with twin pregnancies should be included in the screening that is carried out between 18 and 22 week of gestation. In the case of a negative screening result, $\mathrm{CL}$ measurements should be serially repeated with the aid of a transvaginal ultrasound. The effectiveness of routinely administrated vaginal progesterone, in patients with a normal $\mathrm{CL}$ in their current pregnancy with a previous history of PTB, should be evaluated. In the case of a positive screening result, the patient should be advised to start vaginal progesterone supplementation at a dose of $200 \mathrm{mg}$ daily $(100 \mathrm{mg}$ twice a day) or at a dose of $90 \mathrm{mg}$ in gel until delivery, in an effort to reduce both neonatal mortality and the incidence of neonatal complications. In the case of continued shortening of the cervix without dilation, it appears reasonable to insert a pessary until the 26th week of gestation. Alternatively, in situations were the shortening of the cervix proceeds with dilation of the cervix, despite the use of vaginal progesterone, the use of cervical cerclage should be considered beneficial up to the 24th week of gestation. It is important to note that both the pessary and cervical cerclage should be removed before the onset of uterine contraction. 


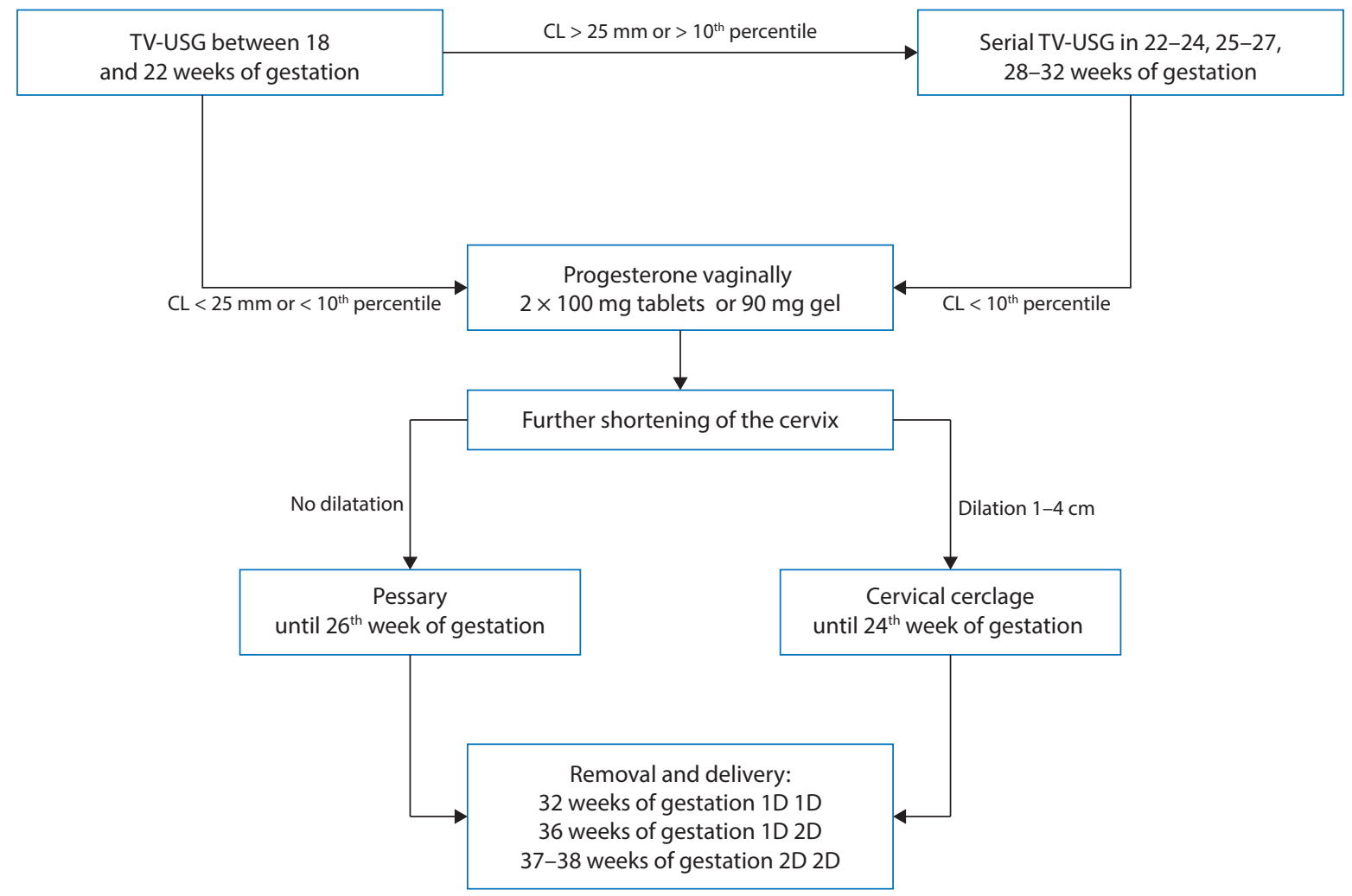

Figure 1. Proposed algorithm for the management of twin pregnancies complicated by asymptomatic shortening of the cervix

Table 1. Summary of the discussed studies that are included in the algorithm

\begin{tabular}{|c|c|c|c|c|}
\hline Author & $\begin{array}{l}\text { Type of } \\
\text { study }\end{array}$ & Objective of the study & $\begin{array}{l}\text { Number of } \\
\text { patient/ } \\
\text { /study }\end{array}$ & Results \\
\hline $\begin{array}{l}\text { Goldenberg } \\
\text { et al. (1996) [9] }\end{array}$ & PCS & $\begin{array}{l}\text { To determine the association } \\
\text { between the presence } \\
\text { a short cervix and the risk } \\
\text { of spontaneous preterm birth } \\
\text { of twins }\end{array}$ & 147 patients & $\begin{array}{l}\mathrm{CL}<25 \mathrm{~mm} \text { at } 24 \text { weeks of gestation is associated with } \\
\text { an increased risk of PTB }<37 \text { weeks of gestation [OR 6.9; } \\
95 \% \mathrm{Cl} 2.0-24.2)]\end{array}$ \\
\hline $\begin{array}{l}\text { Conde- } \\
\text { Agudelo, } \\
\text { Romero et al. } \\
(2010)[10]\end{array}$ & SRM & $\begin{array}{l}\text { To assess the accuracy } \\
\text { of transvaginal sonographic } \\
\text { cervical length }(\mathrm{CL}) \text { in predicting } \\
\text { spontaneous preterm birth in } \\
\text { women with twin pregnancies }\end{array}$ & 21 trials & $\begin{array}{l}\mathrm{CL}<20 \mathrm{~mm} \text { between } 20 \text { and } 24 \text { weeks gestation increases } \\
\text { the risk of PTB }<32 \text { weeks of gestation from } 6.8 \% \text { to } 42.4 \% \text {, } \\
\text { and the risk of PTB }<34 \text { weeks of gestation from } 15.3 \% \text { to } \\
61.9 \% \\
\mathrm{CL}<25 \mathrm{~mm} \text { appeared to increase the risk of PTB }<28 \text { weeks } \\
\text { of gestation from } 3.5 \% \text { to } 25.8 \% \text { and from } 41.2 \% \text { to } \\
75.5 \%<37 \text { weeks of gestation }\end{array}$ \\
\hline $\begin{array}{l}\text { Melamed et al. } \\
\text { (2016) [11] }\end{array}$ & $\mathrm{RCS}$ & $\begin{array}{l}\text { To determine whether } \\
\text { serial measurements of } \mathrm{CL} \\
\text { can improve prediction of PTB } \\
\text { in asymptomatic women } \\
\text { with twin pregnancy }\end{array}$ & 441 patients & $\begin{array}{l}\text { In relation to the single measurement, the serial } C L \\
\text { measurements were associated with an increased detection } \\
\text { rate of PTB }<32 \text { weeks of gestation ( } 69 \% \text { vs. } 28 \% \text { for single } \\
\text { measurement, } p<0.001) \text {, increased positive predictive } \\
\text { value ( } 14.54 \text { vs. } 5.21) \text { and decreased negative predictive } \\
\text { value }(0.32 \text { vs. } 0.76)\end{array}$ \\
\hline $\begin{array}{l}\text { Romero, } \\
\text { Nicolaides } \\
\text { et al. (2012) } \\
\text { [14] }\end{array}$ & $\begin{array}{c}\text { Meta-analysis } \\
\text { of RCT }\end{array}$ & $\begin{array}{l}\text { To determine whether the } \\
\text { use of vaginal progesterone } \\
\text { in asymptomatic women with } \\
\text { a sonographic } \mathrm{CL} \leq 25 \mathrm{~mm} \text { in the } \\
\text { midtrimester reduces the risk } \\
\text { of PTB and improves neonatal } \\
\text { morbidity and mortality }\end{array}$ & 5 trials & $\begin{array}{l}\text { For twin pregnancies with asymptomatic } \mathrm{CL}<25 \mathrm{~mm} \\
\text { in the second trimester, a statistically insignificant trend } \\
\text { toward a reduction in the prevalence of } \mathrm{PBR}<33 \text { weeks } \\
\text { was demonstrated. Vaginal progesterone was shown to be } \\
\text { associated with a } 48 \% \text { reduction in neonatal mortality and } \\
\text { the incidence of neonatal complications (RR } 0.52 ; 95 \% \mathrm{Cl} \\
0.29-0.93 \text { ) }\end{array}$ \\
\hline
\end{tabular}


Table 1. Summary of the discussed studies that are included in the algorithm (cont.)

\begin{tabular}{|c|c|c|c|c|}
\hline Author & $\begin{array}{l}\text { Type of } \\
\text { study }\end{array}$ & Objective of the study & $\begin{array}{l}\text { Number of } \\
\text { patient/ } \\
\text { /study }\end{array}$ & Results \\
\hline $\begin{array}{l}\text { Schuit et al. } \\
\text { (2015) [15] }\end{array}$ & $\begin{array}{l}\text { Meta-analysis } \\
\text { of RCT }\end{array}$ & $\begin{array}{l}\text { To assess the effectiveness } \\
\text { of progesterone treatments } \\
\text { in the prevention of neonatal } \\
\text { morbidity or PTB in twin } \\
\text { pregnancies }\end{array}$ & 13 trials & $\begin{array}{l}\text { In a selected subgroup of patients with CL less than } 25 \mathrm{~mm} \\
\text { before } 24 \text { weeks of gestation, vaginal progesterone } \\
\text { significantly reduced neonatal mortality and the incidence } \\
\text { of neonatal complications (RR } 0.56 ; 95 \% \mathrm{Cl} 0.42-0.75 \text { ) }\end{array}$ \\
\hline $\begin{array}{l}\text { Liem et al. } \\
\text { (2013) [17] }\end{array}$ & RCT & $\begin{array}{l}\text { To assess whether a cervical } \\
\text { pessary could effectively prevent } \\
\text { poor perinatal outcomes }\end{array}$ & 808 patients & $\begin{array}{l}\text { In the subgroup of patients whose } \mathrm{CLs} \text { were between } \\
16 \text { and } 20 \text { weeks was }<25 \text { percentile (in the study } \\
\text { population corresponds to } 38 \mathrm{~mm} \text { ), pessary administration } \\
\text { resulted in the statistically significant prolongation of } \\
\text { pregnancy ( } \mathrm{p}=0.0106, \mathrm{RR} 0.49 ; 95 \% \mathrm{Cl} 0.32-0.77 \text { ). } \\
\text { In addition, the incidence of neonatal complications was } \\
\text { statistically significantly lower ( } \mathrm{p}=0.0106, \mathrm{RR} 0.4,95 \% \mathrm{Cl} \\
0.19-0.83 \text { ), as well as the risk of PTB }<28 \text { weeks of gestation } \\
(p=0.0158, \mathrm{RR} 0.23,95 \% \mathrm{Cl}<0.06-0.87 \text { ) and }<32 \text { weeks } \\
\text { of gestation ( } p=0.0476, \mathrm{RR} 0.49 ; 95 \% \mathrm{Cl} 0.24-0.97 \text { ) }\end{array}$ \\
\hline $\begin{array}{l}\text { Nicolaides } \\
\text { et al. (2016) } \\
\text { [18] }\end{array}$ & RCT & $\begin{array}{l}\text { To evaluate the efficacy of } \\
\text { pessaries administered between } \\
20 \text { and } 24 \text { weeks of gestation for } \\
\text { prevention of PTB among twin } \\
\text { pregnancies }\end{array}$ & 1180 patients & $\begin{array}{l}\text { There were no statistically significant differences in the } \\
\text { incidence of PTB }<34 \text { weeks of gestation (RR } 1.054,95 \% \mathrm{Cl} \\
0.787-1.413 \text { ) as well as neonatal mortality (RR } 0.908,95 \% \mathrm{Cl} \\
0.553-1.491 \text { ), neonatal complications (RR } 1.094 ; 95 \% \mathrm{Cl} \\
0.851-1.407 \text { ) and the incidence of neonatal intensive care } \\
\text { procedures (RR } 1.040 ; 95 \% \mathrm{Cl} 0.871-1.242 \text { ) }\end{array}$ \\
\hline $\begin{array}{l}\text { Goya et al. } \\
\text { (2016) [19] }\end{array}$ & RCT & $\begin{array}{l}\text { The study evaluates the use } \\
\text { of pessaries in PTB prevention } \\
\text { in twin pregnancies with } \\
\text { asymptomatic short cervix }\end{array}$ & 2287 patients & $\begin{array}{l}\text { The use of pessaries significantly reduced the incidence } \\
\text { of PTB before } 34 \text { weeks of gestation (RR } 0.41 ; 95 \% \mathrm{Cl} \\
0.22-0.76 \text { ). In addition, the use of pessaries was associated } \\
\text { with a statistically significantly lower risk of birth weight } \\
\text { less than } 2500 \mathrm{~g} \text { (RR } 0.72 ; 95 \% \mathrm{Cl} 0.54-0.97 \text { ). However, } \\
\text { these changes did not affect the incidence of neonatal } \\
\text { complications (RR } 0.64 ; 95 \% \mathrm{Cl} 0.27-1.50 \text { ) }\end{array}$ \\
\hline $\begin{array}{l}\text { Berghella et al. } \\
\text { (2005) [23] }\end{array}$ & $\begin{array}{l}\text { Meta-analysis } \\
\text { of RCT }\end{array}$ & $\begin{array}{l}\text { To assess the efficacy of cervical } \\
\text { cerclage in both single and } \\
\text { multiple pregnancy }\end{array}$ & 4 trials & $\begin{array}{l}\text { In a subgroup of twin pregnancies with } \mathrm{CL}<25 \mathrm{~mm} \text { the risk } \\
\text { of PTB }<35 \text { weeks of gestation was statistically significantly } \\
\text { increased (RR } 2.15,95 \% \mathrm{Cl} 1.15-4.01 \text { ), and there was } \\
\text { a statistically insignificant increased risk of neonatal death } \\
\text { [RR } 2.66 ; 95 \% \mathrm{Cl} 0.83-8.54 \text { ) }\end{array}$ \\
\hline $\begin{array}{l}\text { Roman et al. } \\
\text { (2016) [24] }\end{array}$ & RCS & $\begin{array}{l}\text { To compare the perinatal } \\
\text { outcomes of twin pregnancies } \\
\text { with a dilated cervix in women } \\
\text { who underwent either cerclage } \\
\text { or expectant management. }\end{array}$ & 8 trials & $\begin{array}{l}\text { In twin pregnancies with cervical dilation ranging from } 1 \text { to } \\
4 \mathrm{~cm} \text {, that underwent cervical cerclage between } 16 \text { and } \\
24 \text { weeks of gestation, there were statistically significant } \\
\text { reductions of } \mathrm{PTB}<34,<32,<28 \text { and }<24 \text { weeks of } \\
\text { gestation }(\mathrm{p}<0.05), 95 \% \mathrm{Cl} 0.03-0.34 \text {, aOR } 0.08,95 \% \mathrm{Cl} \\
0.03-0.34 \text { aOR } 0.05 ; 95 \% \mathrm{Cl} 0.01-0.2 ; \text { aOR } 0.17 ; 95 \% \mathrm{Cl} \\
0.05-0.54 \text {, respectively). In addition, neonatal mortality was } \\
\text { reduced (aOR } 0.24,95 \% \mathrm{Cl} 0.11-0.5 \text { ) as well as neonatal } \\
\text { complications (aOR } 0.05 ; 95 \% \mathrm{Cl} 0.01-0.21 \text { ) }\end{array}$ \\
\hline
\end{tabular}

PCS — prospective cohort study; SRM — systematic review and meta-analysis; RCS — retrospective cohort study; $\mathrm{RCT}$ — randomised controlled trials; $\mathrm{CL}$ — cervical length; PTB - preterm birth

\section{REFERENCES}

1. Norman JE. Preterm labour. Cervical function and prematurity. Best Pract Res Clin Obstet Gynaecol. 2007; 21(5): 791-806, doi: 10.1016/j. bpobgyn.2007.03.002, indexed in Pubmed: 17490914.

2. Shennan A, Jones B. The cervix and prematurity: aetiology, prediction and prevention. Semin Fetal Neonatal Med. 2004; 9(6): 471-479, doi: 10.1016/j.siny.2004.09.001, indexed in Pubmed: 15691785.

3. Vyas NA, Vink JS, Ghidini A, et al. Risk factors for cervical insufficiency after term delivery. Am J Obstet Gynecol. 2006; 195(3): 787-791, doi: 10.1016/j.ajog.2006.06.069, indexed in Pubmed: 16949413.

4. lams JD, Johnson FF, Sonek J, et al. Cervical competence as a continuum: a study of ultrasonographic cervical length and obstetric performance. Am J Obstet Gynecol. 1995; 172(4 Pt 1): 1097-103; discussion 1104, indexed in Pubmed: 7726247.

5. Rozporządzenie Ministra Zdrowia z dnia 9 listopada 2015 r. w sprawie standardów postępowania medycznego przy udzielaniu świadczeń zdro- wotnych w dziedzinie położnictwa i ginekologii zzakresu okołoporodowej opieki położniczo-ginekologicznej, sprawowanej nad kobietą w okresie ciąży, porodu, połogu, w przypadkach występowania określonych powikłań oraz opieki nad kobietą w sytuacji niepowodzeń położniczych.

6. lams J, Goldenberg R, Meis P, et al. The Length of the Cervix and the Risk of Spontaneous Premature Delivery. New England Journal of Medicine. 1996; 334(9): 567-573, doi: 10.1056/nejm199602293340904.

7. Pun TC, Lee CP, Lao TT. The Preterm Prediction Study: Recurrence risk of spontaneous preterm birth. American Journal of Obstetrics and Gynecology. 1998; 178(5): 1104-1105, doi: 10.1016/s0002-9378(98)70569-1.

8. van der Ven J, van Os MA, Kazemier BM, et al. The capacity of mid-pregnancy cervical length to predict preterm birth in low-risk women: a national cohort study. Acta Obstet Gynecol Scand. 2015; 94(11): 1223-1234, doi: 10.1111/aogs.12721, indexed in Pubmed: 26234711.

9. Goldenberg R, lams J, Miodovnik M, et al. The preterm prediction study: Risk factors in twin gestations. American Journal of Obstetrics and Gynecology. 1996; 175(4): 1047-1053, doi: 10.1016/s0002-9378(96)80051-2. 
10. Conde-Agudelo A, Romero R, Hassan SS, et al.Transvaginal sonographic cervical length for the prediction of spontaneous preterm birth in twin pregnancies: a systematic review and metaanalysis. Am J Obstet Gynecol. 2010;203(2): 128. e1-128.12, doi: 10.1016/j.ajog.2010.02.064, indexed in Pubmed: 20576253.

11. Melamed N, Pittini A, Hiersch L, et al. Do serial measurements of cervical length improve the prediction of preterm birth in asymptomatic women with twin gestations? Am J Obstet Gynecol. 2016; 215(5):616.e1-616.e14, doi: 10.1016/j.ajog.2016.06.034, indexed in Pubmed: 27365003.

12. Vayssière $C$, Favre R, Audibert F, et al. Cervical length and funneling at 22 and 27 weeks to predict spontaneous birth before 32 weeks in twin pregnancies: a French prospective multicenter study. Am J Obstet Gynecol. 2002; 187(6): 1596-1604, indexed in Pubmed: 12501070.

13. Yoshimatsu K, Sekiya T, Ishihara K, et al. Detection of the cervical gland area in threatened preterm labor using transvaginal sonography in the assessment of cervical maturation and the outcome of pregnancy. Gynecol Obstet Invest. 2002; 53(3): 149-156, doi: 10.1159/000058366, indexed in Pubmed: 12053099.

14. Romero $\mathrm{R}$, Nicolaides $\mathrm{K}$ et al. Vaginal progesterone in women with an asymptomatic sonographic short cervix in the mid-trimester decreases preterm delivery and neonatal morbidity: a systematic review and meta-analysis of individual patient data. J Obstet Gynecol. 2012; 2: 124-e1.

15. Schuit E, Stock S, Rode L, et al. Effectiveness of progestogens to improve perinatal outcome in twin pregnancies: an individual participant data meta-analysis. BJOG: An International Journal of Obstetrics \& Gynaecology. 2014; 122(1): 27-37, doi: 10.1111/1471-0528.13032.

16. Serra V. Increased doses of vaginal progesterone for the prevention of preterm birth in twin pregnancies: a randomised controlled doubleblind multi-centre trial. BJOG: An International Journal of Obstetrics \& Gynaecology. 2013; 1: 50-57.
17. Liem S, Schuit E, Hegeman M, et al. Cervical pessaries for prevention of preterm birth in women with a multiple pregnancy (ProTWIN): a multicentre, open-label randomised controlled trial. The Lancet. 2013; 382(9901): 1341-1349, doi: 10.1016/s0140-6736(13)61408-7.

18. Goya M, Cabero L, Nicolaides KH, et al. Cervical pessary placement for prevention of preterm birth in unselected twin pregnancies: a randomized controlled trial. Am J Obstet Gynecol. 2016; 214(1): 3.e1-3.e9, doi: 10.1016/j.ajog.2015.08.051, indexed in Pubmed: 26321037.

19. Goya M, Calle Md, Pratcorona L, et al. Cervical pessary to prevent preterm birth in women with twin gestation and sonographic short cervix: a multicenter randomized controlled trial (PECEP-Twins). American Journal of Obstetrics and Gynecology. 2016; 214(2): 145-152, doi: 10.1016/j. ajog.2015.11.012.

20. American College of Obstetricians and Gynecologists. ACOG Practice Bulletin No.142: Cerclage for the management of cervical insufficiency. Obstet Gynecol. 2014; 123(2 Pt 1): 372-379, doi: 10.1097/01. AOG.0000443276.68274.cc, indexed in Pubmed: 24451674.

21. Brown R, Gagnon R, Delisle MF, et al. Maternal Fetal Medicine Committee. Cervical insufficiency and cervical cerclage. J Obstet Gynaecol Can. 2013;35(12): 1115-1127, doi: 10.1016/S1701-2163(15)30764-7, indexed in Pubmed: 24405880.

22. Royal College of Obstetricians \& Gynaecologists. Cervical cerclage. Green-top Guideline No 60. 2015.

23. Berghella V. Cerclage for short cervix on ultrasonography: meta-analysis of trials using individual patient-level data. Obstetrics \& Gynecology 106. 2005; 1: 181-189.

24. Roman A, Rochelson B, Martinelli $P$, et al. Cerclage in twin pregnancy with dilated cervix between 16 to 24 weeks of gestation: retrospective cohort study. Am J Obstet Gynecol. 2016; 215(1): 98.e1-98.e11, doi: 10.1016/j. ajog.2016.01.172, indexed in Pubmed: 26827881. 